DOI: https://doi.org/10.31933/jimt.v2i6 Received: 8 Juni 2021, Revised: 25 Juni 2021, Publish: 31 Juli 2021

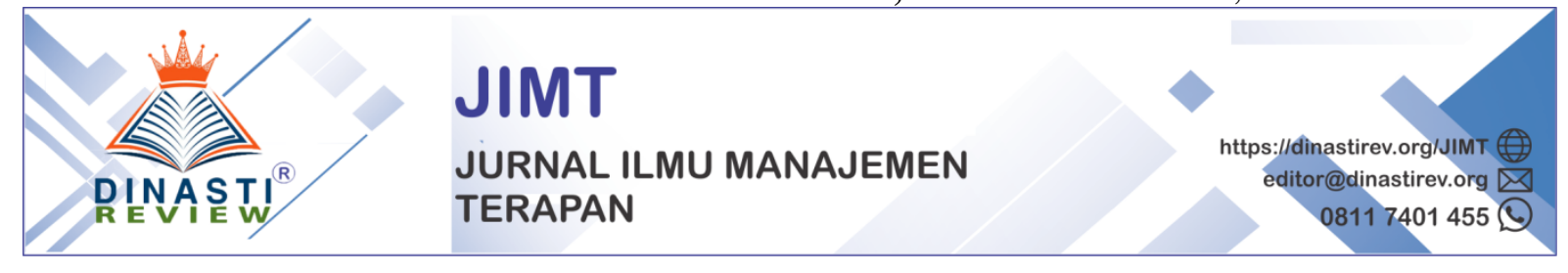

\title{
DETERMINASI SIKAP PENGGUNAAN DAN MINAT BELI (LITERATURE REVIEW MANAJEMEN PEMASARAN)
}

\author{
Inayatullah Fatmawati M \\ ${ }^{1}$ Student of Magister Management, Universitas Mercu Buana Jakarta, \\ inayatullah.fatmawati@gmail.com, 43116110260@ student.mercubuana.ac.id
}

\begin{abstract}
Abstrak: Riset terdahulu atau riset yang relevan sangat penting dalam suatu riset atau artikel ilmiah. Riset terdahulu atau riset yang relevan berfungsi untuk memperkuat teori dan penomena hubungan atau pengaruh antar variable. Artikel imi mereview variabel yang memepengaruhi Minat Beli menggunakan Instagram Shop, maka dilakukan review penelitian terdahulu. Hasil pra riset menunjukkan bahwa diduga persepsi kemudahan, persepsi kemanfaatan dan sikap penggunaan memiliki hubungan baik secara langsung maupun tidak langsung terhadap Minat Beli menggunakan Instagram Shop.
\end{abstract}

Kata Kunci: Persepsi Kemudahan, Persepsi Kemanfaatan, Sikap Penggunaan dan Minat Beli

\section{PENDAHULUAN}

\section{Latar Belakang Masalah}

Setiap mahasiswa baik Strata 1, Strata 2 dan Strata 3, di wajibkan untuk melakukan riset dalam bentuk skripsi, tesis dan disertasi. Begitu juga bagi dosen, peneliti dan tenaga fungsional lainya aktif melakukan riset dan memubuat artikel ilmiah untuk di publikasi pada jurnal-jurnal ilmiah.

Berdasarkan pengalaman empirik banyak mahasiswa dan dosen muda juga peneliti lainnya, kesulitan untuk mencari artikel pendukung dalam riset sebagai penelitian terdahulu atau sebagai penelitian yang relevan. Artikel sebagai peneliti yang relevan di perlukan untuk memperkuat teoti yang di teliti, untuk melihat hubungan antar variable dan membangun hipotesis, juga sangat diperlukan pada bagian pembahasan hasil penelitian.

Artikel ini membahas pengaruh Persepsi Kemudahan dan Persepsi Kemanfaatan terhadap Sikap Penggunaan dan dampaknya terhadap Minat Beli, (Suatu Studi Literatur Manajemen Pemasaran). Tentu tidak semua faktor yang mempengaru Sikap Penggunaan dan Minat Beli pada artikel ini, ini hanya sebagian kecil saja yang akan di kaji dan di review.

Secara rinci tujuan dari penulisan "Literature Review Paper" ini adalah mengetahui pengaruh atau hubungan antara variabel exogen Persepsi Kemudahan dan Persepsi Kemanfaatan terhadap variabel endogen Sikap Penggunaan dan Minat Beli 
1) Pengaruh atau hubungan Persepsi Kemudahan terhadap Sikap Penggunaan

2) Pengaruh atau hubungan Pesepsi Kemanfaatan terhadap Sikap Penggunaan

3) Pengaruh atau hubungan Persepsi Kemudahan terhadap Minat Beli

4) Pengaruh atau hubungan Persepsi Kemanfaatan terhadap Minat Beli

5) Pengaruh atau hubungan Sikap Penggunaan terhadap Minat Beli

\section{KAJIAN TEORI}

\section{Sikap Penggunaan}

F D Davis (Marangunić \& Granić, 2015) menyatakan attitude toward behavior didefinisikan sebagai perasaan-perasaan positif atau negative dari seseorang jika harus melakukan perilaku yang akan ditentukan. Definisi attitude toward behavior menurut Davis yaitu: "an individual's positive or negative feelings about performing the target behavior".

Sikap (attitude) adalah suatu kecenderungan yang dipelajari untuk memberikan respon secara konsisten terhadap suatu objek yang diberikan. (Khazim, 2016) menyatakan bahwa keinginan seseorang untuk melakukan suatu perilaku didasari oleh faktor psikologis seseorang yang merujukpada sikap perilaku yang ditampakan.

Menurut (Jogiyanto, 2017) Sikap terhadap pengaplikasian teknologi (Attitude Toward Using Technology), diartikan sebagai evaluasi dari pemakai tentang keingintahuannya dalam menggunakan teknologi. Sikap terhadap pengaplikasian (Attitude Toward Using) dalam TAM dikonsepkan sebagai sikap terhadap penggunaan sistem yang berbentuk penerimaan atau penolakan sebagai dampak suatu sistem tertentu akan mempermudah usaha yang dikeluarkan Davis

Sikap terhadap pengaplikasian (Attitude Toward Using) juga didefinikan oleh sebagai evaluasi pemakai tentang ketertarikan menggunakan sistem. (Linda Novita \& Giantari, 2016) menyatakan bahwa sikap dapat diukur dengan menggunakan beberapa indikator yaitu senang, percaya, puas, memilih menggunakan dan ingin menggunakan.

Variabel Y1 ini sudah banyak di teliti oleh peneliti sebelumnya di antaranya adalah (Jokar et al., 2017), (Boateng \& Okoe, 2015), (Bashir \& Madhavaiah, 2015), (Jun \& Jaafar, 2011), (Renny et al., 2013), dan lain-lain.

\section{Minat Beli}

Minat beli konsumen adalah sebuah perilaku konsumen dimana konsumen mempunyai keinginan dalam membeli atau memilih suatu produk, berdasarkanpengalaman dalam memilih, menggunakan dan mengkonsumsi atau bahkan menginginkan suatu produk (Kotler \& Keller, 2016).

Minat konsumen adalah seberapa besar kemungkinan konsumen membeli suatu merek atau seberapa besar kemungkinan konsumen untuk berpindah dari satu merek ke merek lainnya. Bila manfaat yang dirasakan lebih besar dibandingkan pengorbanan untuk mendapatkannya, maka dorongan untuk membelinya semakin tinggi (Bimaruci et al., 2020) 
Menurut (Soeaidy et al., 2018) minat beli merupakan perilaku konsumen yang menunjukkan sejauh mana komitmennya untuk melakukan pembelian. Kebutuhan dan keinginan konsumen akan barang dan jasa berkembang dari masa ke masa dan mempengaruhi perilaku mereka dalam pembelian produk. Minat beli adalah bagian dari proses keputusan pembelian dari konsumen, dimana prosesnya diawali dari pengenalan kebutuhan, pencarian informasi, evaluasi alternatif, keputusan pembelian, perilaku pasca pembelian. Dalam tahap evaluasi, konsumen akan menentukan peringkat merek dan membentuk minat pembelian.

Variabel Y2 ini sudah banyak di teliti oleh peneliti sebelumnya di antaranya adalah (Wen et al., 2011), (Rehman et al., 2019), (Sin et al., 2012), (L. X. Teo et al., 2019), (Lim et al., 2017), (Anggita \& Ali, 2017a), (Novansa \& Ali, 2017), (Ali, 2019) dan lain-lain.

\section{Persepsi Kemudahan}

F.D. Davis dalam (Marangunić \& Granić, 2015) perceived ease of use sebuah teknologi didefinisikan sebagai suatu ukuran dimana seseorang percaya bahwa teknologi dapat dengan mudah dipahami dan digunakan

Menurut (Jogiyanto, 2017) Persepsi Kemudahan Penggunaan (Perceived Ease of Use) dapat meyakinkan pengguna bahwasanya teknologi informasi yang akan diaplikasikan adalah suatu hal yang mudah dan bukan merupakan beban bagi mereka.

Penulis mendefinisikan persepsi kemudahan penggunaan teknologi sebagai tingkat dimana seseorang menyakini bahwa penggunaan teknologi informasi merupakan hal yang mudah dan tidak memerlukan usaha keras dari para pemakainya.

Variabel Persepsi Kemudahan sudah banyak di teliti oleh peneliti sebelumnya di antaranya adalah (Safitri, 2019), (Surendran et al., 2016), (Hamid et al., 2016), (Renny et al., 2013), (Yohanda et al., 2019), dan lain-lain.

\section{Persepsi Kemanfaatan}

Perceived usefulness didefinisikan sebagai sejauh mana seseorang percaya bahwa menggunakan suatu teknologi akan meningkatkan kinerja pekerjaannya ("as the extent to which a person believers that using a technology will enhance her or his performance.") Artinya, jika seseorang merasa percaya bahwa sistem informasi berguna maka dia akan menggunakannya. Sebaliknya, jika merasa percaya bahwa sistem informasi kurang berguna dia tidak akan menggunakannya. Dengan kata lain konstruk ini merupakan suatu kepercayaan (belief) tentang proses pengambilan keputusan (Jogiyanto, 2017)

Kemanfaatan (usefulness) merupakan suatu keadaan yang mana individu percaya bahwa penggunaan suatu teknologi tertentu akan meningkatkan kinerjanya. Perceived usefulness didefinisikan sebagai suatu ukuran dimana penggunaan suatu teknologi dipercaya akan mendatangkan manfaat bagi orang yang menggunakannya (Marangunić \& Granić, 2015).

Persepsi kemanfaatan (Perceived Usefulness) adalah merupakan suatu fase dimana seseorang percaya bahwa pemakai suatu sistem tertentu akan dapat menambah prestasi kerja orang tersebut (Safitri, 2019). 
Variabel X2 sudah banyak di teliti oleh peneliti sebelumnya di antaranya adalah (Alsabawy et al., 2016), (Felbermayr \& Nanopoulos, 2016), (Hamid et al., 2016), (Bimaruci et al., 2020), (Pratiwi \& Pratiwi, 2019) dan lain-lain.

\section{METODE PENULISAN}

Metode penulisan artikel ilmiah ini adalah dengan metode kualitatif dan studi literature atau Library Research. Mengkaji Buku-buku literature sesuai dengan teori yang di bahas khusunya di lingkup Manajemen Pemasaran. Disamping itu menganalisis artikel-artikel ilmiah yang bereputasi dan juga artikel ilmiah dari jurnal yang belum bereputasi. Semua artikel ilmiah yang di citasi bersumber dari Mendeley dan Scholar Google.

Dalam penelitian kualitatif, kajian pustaka harus digunakan secara konsisten dengan asumsi-asumsi metodologis. Artinya harus digunakan secara induktif sehingga tidak mengarahkan pertanyaan-pertanyaan yang diajukan oleh peneliti. Salah satu alasan utama untuk melakukan penelitian kualitatif yaitu bahwa penelitian tersebut bersifat eksploratif, (Ali \& Limakrisna, 2013).

Selanjutnya dibahas secara mendalam pada bagian yang berjudul" Pustaka Terkait" (Related Literature) atau Kajian pustaka( "Review of Literature"), sebagai dasar perumusan hipotesis dan selanjutnya akan menjadi dasar untuk melakukan perbandingan dengan hasil atau temuan-temuan yang terungkap dalam penelitian, (Ali \& Limakrisna, 2013).

\section{PEMBAHASAN}

\section{Pengaruh Persepsi Kemudahan terhadap Sikap Penggunaan}

Menurut (Indarsin \& Ali, 2017) kemudahan ini akan berdampak pada perilaku, yaitu semakin tinggi penilaian seseorang tentang kemudahan menggunakan sistem, semakin tinggi pula tingkat pemanfaatan teknologi informasi. Dengan penggunaan teknologi yang mudah, maka pengguna akan semakin berminat menggunakan teknologi tersebut.

Persepsi kemudahan merupakan faktor dominan dalam penerimaan sistem teknologi informasi. Hal ini dibuktikan pada penelitian yang dilakukan (Fitriana \& Wingdes, 2017)

(Ismail, 2016) menunjukkan bahwa Persepsi Kemudahan (Perceived Easy of Use) dipandang sebagai upaya pertama dalam pemahaman penerimaan teknologi smartphone yang terkait dengan Metode operasional.

Variabel Persepsi Kemudahan dan Sikap Penggunaan sudah banyak di teliti oleh peneliti sebelumnya di antaranya adalah Persepsi Kemudahan: (Renny et al., 2013), (Diop et al., 2019), (Kim, 2012), (Akroush \& Al-Debei, 2015), (Jain et al., 2014) dan Sikap Penggunaan: (Chen et al., 2018), (Nguyen et al., 2019), (Bilgihan et al., 2016), (Butt et al., 2016), (Jadhav \& Khanna, 2016) dan lain-lain.

\section{Pengaruh Persepsi Kemanfaatan terhadap Sikap Penggunaan}


Saleh Alharbi (2014) hubungan antara manfaat yang dirasakan dan sikap terhadap penggunaan menunjukkan hubungan yang lebih kuat daripada hubungan antara persepsi kemudahan penggunaan dan sikap terhadap penggunaan.

Made Wahyu Adhiputra (2015) memberikan makna bahwa semakin baik persepsi tentang manfaat (Perceived Usefulnes) yang terbentuk maka semakin yakin pula sikap nasabah yang akan menggunakan (Attitude Toward Using)

Faktor peningkatan efektivitas dan efisiensi adalah tujuan utama dari penggunaan sistem ini. mengemukakan bahwa kebermanfaatan (usefulness) sistem teknologi informasi merupakan manfaat yang diharapkan oleh pengguna saat melaksanakan tugasnya. Seseorang akan menggunakan teknologi informasi jika mengetahui ada manfaat positif yang diperoleh atas penggunaan teknologi informasi tersebut ( $\mathrm{Li}, 2010)$

Variabel Persepsi Kemafaatan dan Minat Beli sudah banyak di teliti oleh peneliti sebelumnya di antaranya adalah Persepsi Kemanfaatan: (Renny et al., 2013), (Vahdat et al., 2020), (Weng et al., 2018), dan Minat Beli: (Karnadjaja et al., 2018), (Ardiyanto \& Kusumadewi, 2020), (Andi Sukma et al., 2019), (T. Teo \& Zhou, 2014), (Lule \& Mwololo Waema, 2012).

\section{Pengaruh Persepsi Kemudahan terhadap Minat Beli}

(Amalia, 2018) Jika prosedur yang dibutuhkan untuk membeli e-ticket sederhana, mudah digunakan, dan tidak memerlukan banyak keterampilan, maka akan dianggap memberikan banyak kegunaan. Hal ini berarti kemudahan penggunaan semakin baik mengakibatkan minat bertransaksi menggunakan online juga baik, apabila kemudahan penggunaan yang semakin rendah maka minat bertransaksi menggunakan online akan menurun.

Persepsi kemudahan merupakan faktor dominan dalam penerimaan sistem teknologi informasi. Hal ini dibuktikan pada penelitian yang dilakukan (Fitriana \& Wingdes, 2017)

Variabel X1 dan Y2 sudah banyak di teliti oleh peneliti sebelumnya di antaranya adalah X1: (Jun \& Jaafar, 2011), (Akroush \& Al-Debei, 2015), (Sidharta \& Sidh, 2014), dan Y2: (Sarkar \& Khare, 2017), (Rauniar et al., 2014), (Shroff et al., 2011), (Hussein, 2017), (Sitorus et al., 2019)

\section{Pengaruh Persepsi Kemanfaatan terhadap Minat Beli}

Perceived ease of use adalah bagaimana mudahnya internet untuk digunakan sebagai belanja medium, konsumen akan cenderung melakukan pembelian atau bertransaksi kembali jika proses yang dilakukannya dirasakan lebih memberi manfaat. (Aziz et al., 2018).

Semakin besar nilai persepsi kemanfaatan (perceived usefulness) bagi konsumen maka akan semakin besar kemungkinan mereka melakukan pembelian (Kian et al., 2017).

Variabel Persepsi Kemanfaatan dan Minat Beli sudah banyak di teliti oleh peneliti sebelumnya di antaranya adalah Persepsi Kemanfaatan: (Muntianah et al., 2012), (Rahman \& 
Dewantara, 2017), dan Minat Beli : (Maskuri et al., 2019), (Irshad \& Ahmad, 2019), (Patel et al., 2017).

\section{Pengaruh Sikap Penggunaan terhadap Minat Beli}

Menurut (Schiffman \& Kanuk, 2010) menyatakan sikap merupakan ekspresi perasaan yang berasal dari dalam diri individu yang mencerminkan apakah seseorang senang atau tidak senang terhadap suatu objek suka atau tidak suka dan setuju atau tidak setuju terhadap suatu objek.

Variabel Sikap Penggunaan dan Minat Beli sudah banyak di teliti oleh peneliti sebelumnya di antaranya adalah Y1: (Diantanti et al., 2018), (Kaushal \& Kumar, 2016), (Saputra et al., 2019) dan Y2: (Sinta Wahyuni \& Sri Darma, 2019), (Nagar, 2018),

\section{Conceptual Framework}

Berdasarkan rumusan masalah penulisan artikel ini dan kajian studi literature review baik dari buku dan artikel yang relevan, maka di perolah rerangka artikel ini seperti di bawah ini.

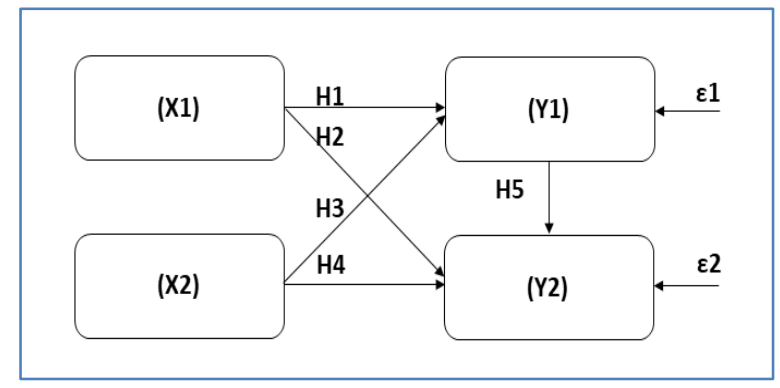

Persepsi Kemudahan dan Persepsi Kemanfaatan memiliki hubungan dan berpengaruh terhadap Sikap Penggunaan dan Minat Beli baik secara langsung maupun tidak langsung.

Selain dari variabel Persepsi Kemudahan dan Persepsi Kemanfaatan yang mempengaruhi Sikap Penggunaan dan Minat Beli masih banyak variabel lain yang mempengaruhinya, di antaranya adalah variabel:

1) Kepercayaan: (Bonsón Ponte et al., 2015), (Permana, 2020), (Rosdiana \& Haris, 2018), (Toto Handiman \& Ali, 2019), and (Indarsin \& Ali, 2017)., (Toto Handiman \& Ali, 2019), (Ali, Mukhtar, et al., 2016)

2) Keamanan: (Choon Ling et al., 2011), (Kamalul Ariffin et al., 2018), (Sarjita, 2020)

3) Kualitas Informasi : (Anggita \& Ali, 2017a), (Hsu et al., 2012), (Filieri et al., 2018), (Djojo \& Ali, 2012), and (Desfiandi et al., 2017),

4) Kualitas Produk: (Desfiandi et al., 2017), (M \& Ali, 2017), (Ali, Narulita, et al., 2018), (M \& Ali, 2017), (Ali, Evi, et al., 2018), (Prihartono \& Ali, 2020), (Riyanto et al., 2017), (Maisah \& Ali, 2020), (Brata et al., 2017), (Thanh Nguyen et al., 2019), (Ali, 2019), and (Anggita \& Ali, 2017b).

5) Citra Merek: (Ali, Limakrisna, et al., 2016), (M \& Ali, 2017), (Ali \& Mappesona, 2016), (Ali, Narulita, et al., 2018), (Novansa \& Ali, 1926), and (Toto Handiman \& Ali, 2019). 


\section{KESIMPULAN DAN SARAN}

\section{Kesimpulan}

Berdasarkan rumusan artikel, hasil dan pembahasan, maka dapat di di rumuskan hipotesis untuk riset selanjutnya:

1. Persepsi Kemudahan berpengaruh terhadap Sikap Penggunaan.

2. Persepsi Kemanfaatan berpengaruh terhadap Sikap Penggunaan.

3. Persepsi Kemudahan berpengaruh terhadap Minat Beli.

4. Persepsi Kemanfaatan berpengaruh terhadap Minat Beli.

5. Sikap Penggunaan berpengaruh terhadap Minat Beli.

\section{Saran}

Berdasarkan Kesimpulan di atas, maka saran pada artikel ini adalah bahwa masih banyak factor lain yang mempengaruhi Sikap Penggunaan dan Minat Beli, selain dari Persepsi Kemudahan dan Persepsi Kemanfaatan oleh karena itu masih di perlukan kajian yang lebih lanjut untuk mencari faktor-faktor lain apa saja yang dapat memepengaruhi Sikap Penggunaan dan Minat Beli selain yang di teliti pada arikel ini.

\section{DAFTAR PUSTAKA}

Akroush, M. N., \& Al-Debei, M. M. (2015). An integrated model of factors affecting consumer attitudes towards online shopping. Business Process Management Journal. https://doi.org/10.1108/BPMJ-02-2015-0022

Ali, H. (2019). Purchase Decision and Repurchase Models: Product Quality and Process Analysis (Case Study of House Ownership Credit Financing in Permata Sharia Bank Jakarta). Scholars Bulletin. https://doi.org/10.36348/sb.2019.v05i09.006

Ali, H., Evi, N., \& Nurmahdi, A. (2018). The Influence of Service Quality , Brand Image and Promotion on Purchase Decision at MCU Eka Hospital. Business and Management Studies. https://doi.org/10.21276/sjbms.2018.3.1.12

Ali, H., Limakrisna, N., \& Jamaluddin, S. (2016). Model of customer satisfaction: The empirical study at Bri in Jambi. International Journal of Applied Business and Economic Research.

Ali, H., \& Mappesona, H. (2016). Build brand image: Analysis Service Quality and Product Quality (case study at Giant Citra Raya). International Journal of Economic Research.

Ali, H., Mukhtar, \& Sofwan. (2016). Work ethos and effectiveness of management transformative leadership boarding school in the Jambi Province. International Journal of Applied Business and Economic Research.

Ali, H., Narulita, E., \& Nurmahdi, A. (2018). Saudi Journal of Business and Management Studies ( SJBMS ) The Influence of Service Quality, Brand Image and Promotion on Purchase Decision at MCU Eka Hospital. Business and Management Studies. https://doi.org/10.21276/sjbms.2018.3.1.12

Alsabawy, A. Y., Cater-Steel, A., \& Soar, J. (2016). Determinants of perceived usefulness of e-learning systems. Computers in Human Behavior. https://doi.org/10.1016/j.chb.2016.07.065 
Amalia, S. N. A. (2018). Faktor-Faktor Yang Mempengaruhi Minat Individu Terhadap Financial Technology (Fintech) Syariah (Paytren) Sebagai Salah Satu Alat Transaksi Pembayaran (PendekatanTechnology Acceptance Model (TAM) dan Theory Of Planned Behavior (TPB). Iqtishaduna.

Andi Sukma, E., Hadi, M., Nikmah, F., Administrasi Niaga, J., \& Negeri Malang, P. (2019). Pengaruh Technology Acceptance Model (Tam) Dan Trust Terhadap Intensi Pengguna Instagram. Jurnal Riset Ekonomi Dan Bisnis.

Anggita, R., \& Ali, H. (2017a). The Influence of Product Quality, Service Quality and Price to Purchase Decision of SGM Bunda Milk (Study on PT. Sarihusada Generasi Mahardika Region Jakarta, South Tangerang District). Scholars Bulletin.

Anggita, R., \& Ali, H. (2017b). The Influence of Product Quality, Service Quality and Price to Purchase Decision of SGM Bunda Milk (Study on PT. Sarihusada Generasi Mahardika Region Jakarta, South Tangerang District). Scholars Bulletin. https://doi.org/10.21276/sb

Ardiyanto, F., \& Kusumadewi, H. (2020). Pengintegrasian Technology Acceptance Model (TAM) dan Kepercayaan Konsumen pada Marketplace Online Indonesia. Jurnal Inspirasi Bisnis Dan Manajemen. https://doi.org/10.33603/jibm.v3i2.2659

Aziz, A., Mursityo, Y. T., \& Rachmadi, A. (2018). Analisis Penggunaan Media Sosial Instagram dan Pengaruhnya Terhadap Business Performance Satisfaction (Studi Pada Pengusaha Kuliner Di Kota Malang). Jurnal Pengembangan Teknologi Informasi Dan Ilmu Komputer.

Bashir, I., \& Madhavaiah, C. (2015). Consumer attitude and behavioural intention towards Internet banking adoption in India. Journal of Indian Business Research. https://doi.org/10.1108/JIBR-02-2014-0013

Bilgihan, A., Kandampully, J., \& Zhang, T. (Christina). (2016). Towards a unified customer experience in online shopping environments: Antecedents and outcomes. International Journal of Quality and Service Sciences. https://doi.org/10.1108/IJQSS-07-2015-0054

Bimaruci, H., Agung Hudaya, \& Hapzi Ali. (2020). MODEL OF CONSUMER TRUST ON TRAVEL AGENT ONLINE: ANALYSIS OF PERCEIVED USEFULNESS AND SECURITY ON RE-PURCHASE INTERESTS (CASE STUDY TIKET.COM). Dinasti International Journal of Economics, Finance \& Accounting. https://doi.org/10.38035/dijefa.v1i1.227

Boateng, H., \& Okoe, A. F. (2015). Consumers' attitude towards social media advertising and their behavioural response: The moderating role of corporate reputation. Journal of Research in Interactive Marketing. https://doi.org/10.1108/JRIM-01-2015-0012

Bonsón Ponte, E., Carvajal-Trujillo, E., \& Escobar-Rodríguez, T. (2015). Influence of trust and perceived value on the intention to purchase travel online: Integrating the effects of assurance on trust antecedents. Tourism Management. https://doi.org/10.1016/j.tourman.2014.10.009

Brata, B. H., Husani, S., \& Ali, H. (2017). The Importance of Quality Products, Price, Promotion, and Location to Product Purcese Decision on Nitchi At PT. Jaya Swarasa Agung in Central Jakarta. Saudi Journal of Business and Management Studies. https://doi.org/10.21276/sjbms

Butt, I., Tabassam, S., Chaudhry, N. G., \& Nusair, K. (2016). Using technology acceptance 
model to study adoption of online shopping in an emerging economy. Journal of Internet Banking and Commerce.

Chen, Y. M., Hsu, T. H., \& Lu, Y. J. (2018). Impact of flow on mobile shopping intention. Journal of Retailing and Consumer Services. https://doi.org/10.1016/j.jretconser.2017.04.004

Choon Ling, K., Bin Daud, D., Hoi Piew, T., Keoy, K. H., \& Hassan, P. (2011). Perceived Risk, Perceived Technology, Online Trust for the Online Purchase Intention in Malaysia. International Journal of Business and Management. https://doi.org/10.5539/ijbm.v6n6p167

Desfiandi, A., Fionita, I., \& Ali, H. (2017). Implementation of the information systems and the creative economy for the competitive advantages on tourism in the province of Lampung. International Journal of Economic Research.

Diantanti, N. P., Sunaryo, S., \& Rahayu, M. (2018). PERBANDINGAN PENGGUNAAN LOCAL-NAME BRAND DAN FOREIGN-NAME BRAND PADA PRODUK FASHION DI KOTA MALANG. Jurnal Bisnis Dan Manajemen. https://doi.org/10.26905/jbm.v5i1.2319

Diop, E. B., Zhao, S., \& Duy, T. Van. (2019). An extension of the technology acceptance model for understanding travelers' adoption of variable message signs. PLOS ONE. https://doi.org/10.1371/journal.pone.0216007

Djojo, A., \& Ali, H. (2012). Information technology service performance and client's relationship to increase banking image and its influence on deposits customer banks loyalty (A survey of Banking in Jambi). In Archives Des Sciences.

Felbermayr, A., \& Nanopoulos, A. (2016). The Role of Emotions for the Perceived Usefulness in Online Customer Reviews. Journal of Interactive Marketing. https://doi.org/10.1016/j.intmar.2016.05.004

Filieri, R., McLeay, F., Tsui, B., \& Lin, Z. (2018). Consumer perceptions of information helpfulness and determinants of purchase intention in online consumer reviews of services. Information and Management. https://doi.org/10.1016/j.im.2018.04.010

Fitriana, A., \& Wingdes, I. (2017). Analisis TAM Terhadap Faktor-Faktor yang Mempengaruhi Konsumen Menggunakan e-Money Indomaret Card di Pontianak. Techno.Com. https://doi.org/10.33633/tc.v16i4.1515

Hamid, A. A., Razak, F. Z. A., Bakar, A. A., \& Abdullah, W. S. W. (2016). The Effects of Perceived Usefulness and Perceived Ease of Use on Continuance Intention to Use EGovernment. Procedia Economics and Finance. https://doi.org/10.1016/s22125671(16)00079-4

Hamdan, H., \& Paijan, P. (2020). Utilitarian values and hedonic values of women coffee lovers. Dinasti International Journal of Education Management and Social Science, 2(2), 310-322. https://doi.org/10.31933/dijemss.v2i2.666

Hamdan, H., \& Yuliantini, T. (2021). Purchase behavior : online tour package. Dinasti International Journal of Management Science, 2(3), 420-434. https://doi.org/10.31933/dijms.v2i3.704

Hsu, C. L., Chang, K. C., \& Chen, M. C. (2012). The impact of website quality on customer satisfaction and purchase intention: Perceived playfulness and perceived flow as mediators. Information Systems and E-Business Management. 
https://doi.org/10.1007/s10257-011-0181-5

Hussein, Z. (2017). Leading to Intention: The Role of Attitude in Relation to Technology Acceptance Model in E-Learning. Procedia Computer Science. https://doi.org/10.1016/j.procs.2017.01.196

Indarsin, T., \& Ali, H. (2017). Attitude toward Using m-Commerce: The Analysis of Perceived Usefulness Perceived Ease of Use, and Perceived Trust: Case Study in Ikens Wholesale Trade, Jakarta - Indonesia. Saudi Journal of Business and Management Studies. https://doi.org/10.21276/sjbms.2017.2.11.7

Irshad, M., \& Ahmad, M. S. (2019). Impact of Consumers' Online Motivations on the Online Purchase Intentions: Mediating Role of Consumers' Attitudes towards Social Media Marketing. Business \& Economic Review. https://doi.org/10.22547/ber/11.3.4

Ismail, H. A. (2016). Intention to Use Smartphone Through Perceived Compatibility, Perceived Usefulness, and Perceived Ease of Use. Jurnal Dinamika Manajemen. https://doi.org/10.15294/jdm.v7i1.5748

Jadhav, V., \& Khanna, M. (2016). Factors influencing online buying behavior of college students: A qualitative analysis. Qualitative Report.

Jain, M. D., Goswami, M. S., \& Bhutani, M. S. (2014). Consumer Behavior towards Online Shopping: An Empirical Study from Delhi. IOSR Journal of Business and Management. https://doi.org/10.9790/487x-16946572

Jogiyanto. (2017). Konsep Dasar Sistem Informasi. Konsep Dasar Sistem Informasi.

Jokar, N. K., Noorhosseini, S. A., Allahyari, M. S., \& Damalas, C. A. (2017). Consumers' acceptance of medicinal herbs: An application of the technology acceptance model (TAM). Journal of Ethnopharmacology. https://doi.org/10.1016/j.jep.2017.06.017

Jun, G., \& Jaafar, N. I. (2011). A Study on Consumers' Attitude towards Online Shopping in China. International Journal of Business and Social Science.

Kamalul Ariffin, S., Mohan, T., \& Goh, Y. N. (2018). Influence of consumers' perceived risk on consumers' online purchase intention. Journal of Research in Interactive Marketing, 12(3), 309-327. https://doi.org/10.1108/JRIM-11-2017-0100

Karnadjaja, C. C., Tulipa, D., \& Lukito, R. S. H. (2018). Pengaruh Persepsi Risiko, Manfaat, Dan Kemudahan Penggunaan Terhadap Minat Belanja Online Melalui Kepercayaan Dan Sikap Pada Konsumen Zalora Di Surabaya. Kajian Ilmiah Mahasiswa Manajemen.

Kaushal, S. K., \& Kumar, R. (2016). Influence of Attitude towards Advertisement on Purchase Intention: Exploring the Mediating Role of Attitude towards Brand Using SEM Approach. The IUP Journal of Marketing Management.

Khazim, I. (2016). PENGARUH STRATEGI INTERNET MARKETING TERHADAP PERILAKU KONSUMEN LAZADA.CO.ID DALAM BERBELANJA ONLINE MELALUI VARIABEL ELECTRONIC WORD OF MOUTH (EWOM). Jurnal Ilmiah Ekonomi Bisnis.

Kian, T. P., Boon, G. H., Fong, S. W. L., \& Ai, Y. J. (2017). Factors that influence the consumer purchase intention in social media websites. International Journal of Supply Chain Management.

Kim, J. B. (2012). An empirical study on consumer first purchase intention in online shopping: Integrating initial trust and TAM. Electronic Commerce Research. 
https://doi.org/10.1007/s10660-012-9089-5

Kotler, P., \& Keller, K. L. (2016). Marketing Mangement. In Pearson Edition Limited.

Li, L. (2010). A critical review of technology acceptance literature. Southwest Decisino Sciences Institute.

Lim, X. J., Mohd Radzol, A. R. bt, Cheah, J.-H. (Jacky), \& Wong, M. W. (2017). The Impact of Social Media Influencers on Purchase Intention and the Mediation Effect of Customer Attitude. Asian Journal of Business Research. https://doi.org/10.14707/ajbr.170035

Linda Novita, N., \& Giantari, I. (2016). PERAN SIKAP DALAM MEMEDIASI PENGARUH PERCEIVED USEFULNESS TERHADAP NIAT MENGGUNAKAN INTERNET BANKING DI KOTA DENPASAR. None.

Lule, I. ;Omwansa tonny K., \& Mwololo Waema, T. (2012). Application of Technology Acceptance Model ( TAM ) in M-Banking Adoption in Kenya. International Journal of Computing and ICT Research.

M, A., \& Ali, H. (2017). MODEL KEPUASAN PELANGGAN: ANALISIS KUALITAS PRODUK DAN KUALITAS LAYANAN TERHADAP CITRA MEREK PADA GIANT CITRA RAYA JAKARTA. Jurnal Manajemen. https://doi.org/10.24912/jm.v21i3.254

Maisah, \& Ali, H. (2020). Entrepreneurship culture development process: Implementation of Islamic education values in the Batik Jambi (case study in Seberang Jambi community). Talent Development and Excellence.

Marangunić, N., \& Granić, A. (2015). Technology acceptance model: a literature review from 1986 to 2013. Universal Access in the Information Society. https://doi.org/10.1007/s10209-014-0348-1

Maskuri, M. A., Kurniawan, E. N., Wardani, M. K., \& Andriyani, M. (2019). KEPERCAYAAN, KEMUDAHAN PENGGUNAAN DAN ELECTRONIC WORD OF MOUTH TERHADAP MINAT BELI ONLINE. Jurnal Manajemen Kewirausahaan. https://doi.org/10.33370/jmk.v16i2.348

Muntianah, S. T., Astuti, E. S., \& Azizah, D. F. (2012). Pengaruh Minat Perilaku Terhadap Actual Use Teknologi Informasi Dengan Pendekatan Technology Acceptance Model (TAM) (Studi kasus pada kegiatan belajar Mahasiswa Fakultas Ilmu Administrasi Universitas Brawijaya Malang). Profit.

Nagar, K. (2018). Assessing the Impact of Online Retailer Models on Consumer's Attitude and Purchase Intentions. IIM Kozhikode Society \& Management Review. https://doi.org/10.1177/2277975217733871

Nguyen, T. T. H., Nguyen, N., Nguyen, T. B. L., Phan, T. T. H., Bui, L. P., \& Moon, H. C. (2019). Investigating consumer attitude and intention towards online food purchasing in an emerging economy: An extended TAM approach. Foods. https://doi.org/10.3390/foods8110576

Novansa, H., \& Ali, H. (1926). Purchase Decision Model: Analysis of Brand Image, Brand Awareness and Price (Case Study SMECO Indonesia SME products). Saudi Journal of Humanities and Social Sciences. https://doi.org/10.21276/sjhss

Novansa, H., \& Ali, H. (2017). Purchase Decision Model: Analysis of Brand Image, Brand Awareness and Price (Case Study SMECO Indonesia SME products). Saudi Journal of 
Humanities and Social Sciences. https://doi.org/10.21276/sjhss

Patel, J. D., Gadhavi, D. D., \& Shukla, Y. S. (2017). Consumers' responses to cause related marketing: moderating influence of cause involvement and skepticism on attitude and purchase intention. International Review on Public and Nonprofit Marketing. https://doi.org/10.1007/s12208-016-0151-1

Permana, A. I. (2020). PENGARUH KUALITAS WEBSITE, KUALITAS PELAYANAN, DAN KEPERCAYAAN PELANGGAN TERHADAP MINAT BELI PELANGGAN DI SITUS BELANJA ONLINE BUKALAPAK. EKONOMI BISNIS. https://doi.org/10.33592/jeb.v25i2.422

Pratiwi, B. V., \& Pratiwi, R. (2019). Pengaruh Perceived Ease of Use , Perceived Usefulness dan Web Quality Terhadap Minat Beli E-Ticketing Pesawat dengan Trust Sebagai Variabel Intervening (Studi Empiris pada Pengguna Traveloka). MDP Business School.

Prihartono, \& Ali, H. (2020). The promises ethics and marketing concept strategy as a competitive advantage on private higher education (A survey on perception of product attributes and promotion mix in Indonesia). Talent Development and Excellence.

Rahman, A., \& Dewantara, R. Y. (2017). Pengaruh Kemudahan Penggunaan dan Kemanfaatan Teknologi Informasi Terhadap Minat Menggunakan Situs Jual Beli Online. Jurnal Admonistrasi Bisnis.

Rauniar, R., Rawski, G., Yang, J., \& Johnson, B. (2014). Technology acceptance model (TAM) and social media usage: An empirical study on Facebook. Journal of Enterprise Information Management. https://doi.org/10.1108/JEIM-04-2012-0011

Rehman, S. U., Bhatti, A., Mohamed, R., \& Ayoup, H. (2019). The moderating role of trust and commitment between consumer purchase intention and online shopping behavior in the context of Pakistan. Journal of Global Entrepreneurship Research. https://doi.org/10.1186/s40497-019-0166-2

Renny, Guritno, S., \& Siringoringo, H. (2013). Perceived Usefulness, Ease of Use, and Attitude Towards Online Shopping Usefulness Towards Online Airlines Ticket Purchase. Procedia - Social and Behavioral Sciences. https://doi.org/10.1016/j.sbspro.2013.06.415

Riyanto, S., Adila, L., \& Ali, H. (2017). The Effect of Incentives And Job Enthusiasm To Productivity of Go-Jek Driver At PT . Go-Jek Indonesia. Journal of Research in Business and Management.

Rosdiana, R., \& Haris, I. A. (2018). Pengaruh Kepercayaan Konsumen Terhadap Minat Beli Produk Pakaian Secara Online. International Journal of Social Science and Business. https://doi.org/10.23887/ijssb.v2i3.16240

Safitri, M. (2019). Pengaruh Trust, Perceived Benefits and Ease of Use Terhadap Keputusan Penggunaan E-Wallet. Journal of Chemical Information and Modeling, 53(9), 16891699.

Saputra, R. A., Suharjo, B., \& Sukandar, D. (2019). Exploring the Impact of Celebrity Endorsements on The Attitudes And Purchasing Intention in Instagram. Indonesian Journal of Business and Entrepreneurship. https://doi.org/10.17358/ijbe.5.2.107

Sarjita. (2020). Pengaruh Kepercayaan dan Keamanan Terhadap Minat Beli Konsumen Secara Online Pada Situs OLX. Jurnal Bisnis, Manajemen, Dan Akuntansi. 
Sarkar, S., \& Khare, A. (2017). Moderating effect of price perception on factors affecting attitude towards online shopping. Journal of Marketing Analytics. https://doi.org/10.1057/s41270-017-0018-2

Schiffman, L. G., \& Kanuk, L. L. (2010). Consumer Behavior 10th Edition. Pearson Education.

Shroff, R. H., Deneen, C. C., \& Ng, E. M. W. (2011). Analysis of the technology acceptance model in examining students' behavioural intention to use an e-portfolio system. Australasian Journal of Educational Technology. https://doi.org/10.14742/ajet.940

Sidharta, I., \& Sidh, R. (2014). Pengukuran Persepsi Manfaat Dan Persepsi Kemudahan Terhadap Sikap Serta Dampaknya Atas Penggunaan Ulang Online Shopphing Pada ECommerce. Jurnal Computech \& Bisnis.

Sin, S. S., Nor, K. M., \& Al-Agaga, A. M. (2012). Factors Affecting Malaysian young consumers' online purchase intention in social media websites. Procedia - Social and Behavioral Sciences. https://doi.org/10.1016/j.sbspro.2012.03.195

Sinta Wahyuni, N. W., \& Sri Darma, G. (2019). Mobile Advertising, Product Social Value dan Purchase Intention pada Instagram. Jurnal Manajemen Bisnis. https://doi.org/10.38043/jmb.v16i4.2253

Sitorus, S. D., Kholid, M., \& Mawardi. (2019). PENGARUH PERSEPSI KEMUDAHAN, PERSEPSI RISIKO, DAN KEPERCAYAAN KONSUMEN TERHADAP MINAT BELI ONLINE (Studi pada Mahasiswa Pengguna Aplikasi Jual Beli Online Carousell). Jurnal Administrasi Bisnis (JAB)|.

Soeaidy, M., Taufiq, A., \& Mandasari, A. (2018). Stimuli Pada Generasi Millennial Untuk Mau Membayar Harga Premium Fashion Muslim Melalui Status Merek Dan Preferensi Merek. Jurnal Ekonomi Manajemen.

Surendran, P., Tam, M., Abdullah, N. C., Mustapha, R., Ahlan, A. R., Al-Adwan, A., Adwan, A. A.-, Smedley, J., Al-sayyed, F., Abdalhaq, B., Alwahaishi, S., Davis, F. D., Mtebe, J. S., Nan, N., Sheahadeh, R. M., Maqableh, M., Al-zoubi, M. O., Akhorshaideh, A. O., Al-sham, M. K., ... Venkatesh, V. (2016). ONLINE SHOPPING ACCEPTANCE MODEL - A CRITICAL SURVEY OF CONSUMER FACTORS IN ONLINE SHOPPING. MIS Quarterly. https://doi.org/10.1287/mnsc.46.2.186.11926

Teo, L. X., Leng, H. K., \& Phua, Y. X. P. (2019). Marketing on Instagram: Social influence and image quality on perception of quality and purchase intention. International Journal of Sports Marketing and Sponsorship. https://doi.org/10.1108/IJSMS-04-2018-0028

Teo, T., \& Zhou, M. (2014). Explaining the intention to use technology among university students: A structural equation modeling approach. Journal of Computing in Higher Education. https://doi.org/10.1007/s12528-014-9080-3

Thanh Nguyen, P., Ali, H., \& Agung Hudaya. (2019). MODEL BUYING DECISION AND REPEAT PURCHASE: PRODUCT QUALITY ANALYSIS (Case Study of Bank Permata Syariah Jakarta KPR Financing Customers). Dinasti International Journal of Management Science. https://doi.org/10.31933/dijms.v1i1.29

Toto Handiman, U., \& Ali, H. (2019). The Influence of Brand Knowledge and Brand Relationship On Purchase Decision Through Brand Attachment. In International Journal of Business Marketing and Management (IJBMM).

Vahdat, A., Alizadeh, A., Quach, S., \& Hamelin, N. (2020). Would you like to shop via 
mobile app technology? The technology acceptance model, social factors and purchase intention. Australasian Marketing Journal. https://doi.org/10.1016/j.ausmj.2020.01.002

Wen, C., Prybutok, V. R., \& Xu, C. (2011). An integrated model for customer online repurchase intention. Journal of Computer Information Systems. https://doi.org/10.1080/08874417.2011.11645518

Weng, F., Yang, R.-J., Ho, H.-J., \& Su, H.-M. (2018). A TAM-Based Study of the Attitude towards Use Intention of Multimedia among School Teachers. Applied System Innovation. https://doi.org/10.3390/asi1030036

Yohanda, A. R., Masdupi, E., \& Engriani, Y. (2019). The Influence of Promotion, Perceived Ease of Use, and Price Toward Repurchase Intention Transportation Services Go-jek on Students in Universitas Negeri Padang. Jurnal Kajian Manajemen Dan Wirausaha, 1(1), 2019. 